\title{
ISD: A New Methodological Approach for Measuring the Sustainability of the German Energy System
}

\author{
Holger Schlör, Wolfgang Fischer, and Jürgen-Friedrich Hake \\ Forschungszentrum Jülich, Wilhelm-Johnen-Straße, 52428 Jülich, Germany \\ Correspondence should be addressed to Holger Schlör, h.schloer@fz-juelich.de \\ Received 18 January 2011; Revised 21 April 2011; Accepted 6 May 2011 \\ Academic Editor: Ali M. Kutan \\ Copyright ( 2011 Holger Schlör et al. This is an open access article distributed under the Creative Commons Attribution License, \\ which permits unrestricted use, distribution, and reproduction in any medium, provided the original work is properly cited.
}

The research community has developed three main concepts and indicator systems to measure sustainability: the capital concept, the ecological concept and the multidimensional concept. Whereas a lot of research has been dedicated to the pros and cons of the three/four-pillar sustainability concept, to the shaping of the pillars and their indicators, research on standardized methods to aggregate the indicators to one index is lacking. However, a useful model exists-the GDP-which summarizes the different economic activities of various social actors in one index. An overall sustainability index has the advantage that the sustainability of a system can be expressed in one index. This allows the sustainability status of a system to be better communicated both to the public and to politicians. Against this background, we developed the Index of Sustainable Development (ISD) to measure the sustainability of systems described by multidimensional sustainability concepts. We demonstrate that it is possible to aggregate sustainability indicators of the multidimensional sustainability concepts to one index. We have chosen exemplarily the German sustainability strategy and selected the energy indicators within it because of the importance of the energy sector and due to the good statistical database in this sector.

\section{Sustainability Indicators for the German Energy Sector}

1.1. Introduction. The discussion about alternative welfare and sustainability measures started in the 1960s when Tobin and Nordhaus developed the Measure of Economic Welfare (MEW) [1]. With their pivotal paper "Is Growth obsolete?" they also laid the foundation for the later development of sustainability indicator measures [1-4] and for green accounting [5-7].

This discussion took a new direction in 1992, when the 1992 UN Rio de Janeiro conference adopted Agenda 21 [8]. Chapter 40 of Agenda 21, one of the main documents of the 1992 UN Rio de Janeiro conference, encourages the nations to develop indicators of sustainable development to provide a solid basis "for decision-making at all levels and to contribute to a self-regulating sustainability of integrated environment and development systems" [8]. For this duty, a special UN commission, the Commission on Sustainable Development (CSD), was founded to guarantee the effective subsequent implementation of the 1992 Rio agenda.
An important aspect of the work of the CSD is the development of indicator systems for measuring sustainable development. The Commission called upon countries, international governments, and nongovernmental organizations to take part in the process of developing indicator concepts according to the default of Agenda 21 [8, chapter 40.6]. The first indicator system of CSD was published in 1996 and consisted of 134 indicators, which were assigned to the three pillars of sustainability [9-11]. The UN CSD revised their approach in 2001 and again in 2007. The idea behind the multidimensional sustainability concepts is to focus on the economic, social, and ecological problems, which have to be addressed and solved simultaneously to ensure that development is sustainable. In these multidimensional concepts, such as the UN CSD approach, a single sustainability indicator defines a key issue, which characterizes a certain aspect of sustainability in the observed system. Sustainability indicators, if developed well, capture the complexity and order of the systems, and they offer knowledge about the system that can be communicated to decision makers and the general public [12]. Sustainability indicators measure 
the difference between current conditions of a society and a reference situation defined as sustainable [13]. Sustainability indicator systems contain a certain number of indicators that serve to measure the functioning and the interdependence of the analyzed system, and they enable us to measure and evaluate the consequences of this interaction. They can be used to analyze ecological, economic, and social goals in the overall system as well as in the subsystem.

As a result of the UN test phase, in which Germany worked intensively with its UN partners, Germany also decided to develop a more pillar-oriented sustainability strategy in preparation for the Johannesburg Conference in 2002. The new sustainability strategy was known as "Perspectives for Germany" [14] and contained a number of indicators and targets for almost all indicators. Whereas a lot of research has been dedicated to the pros and cons of these concepts, to the shaping of the pillars, their indicators and the adequate goals of sustainable development, quite surprisingly, research on standardized methods to aggregate the indicators to one index is lacking.

Therefore, the basic idea of our index (Index of Sustainable Development) is to help close this research gap and to define an aggregated index concept for the multidimensional sustainability concepts in order to generate clear measurement results, such as the case with the GDP, in sustainability science. We will also demonstrate that it is necessary to define the sustainability goals and the database and, in particular, to define the calculation method explicitly. We have selected the German sustainability strategy for our analysis.

1.2. Sustainability Strategy of the German Government. Based on the multidimensional UN sustainability concept, the German Federal Government defined in 2002 a quantitative sustainable development strategy for Germany [14]. In preparation for the Rio+10 Conference in Johannesburg, the German Federal Government sought to fulfill its obligations entered into at the United Nations Conference on Environment and Development. At that conference, States had committed themselves to creating the necessary institutional conditions for the integration of sustainability concepts into national policies and compiling a national sustainability strategy [15]. The Sustainability Strategy of the German Government defines a sustainable order for Germany on the basis of the following four key issues [14]:

(1) intergenerational equity,

(2) quality of life,

(3) social cohesion,

(4) international responsibility.

The Government set up indicators and sustainability goals for these key issues. Twenty-one topics and 34 indicators (see the Appendix) were chosen to measure the sustainability of the Government's policy [14]. This sustainable strategy was the first attempt by the German Federal Government to define a quantitative sustainable order for Germany [16].

We will concentrate our analysis on the energy indicators of this sustainability strategy because of the importance of energy for sustainable development and the improvement of the people's living conditions. The Brundtland Commission wrote in 1987: "Energy is necessary for daily survival. Future development crucially depends on its long-term availability" [17]. Furthermore, the database for the energy sector was most suitable for demonstrating our new research method.

We selected the 15 energy indicators (Table 1) from the German Sustainability Strategy which can be allocated to the three pillars of sustainability: the environmental aspects of the energy system are defined by eight indicators (air quality, emissions of $\mathrm{CO}_{2}$ (carbon dioxide), $\mathrm{SO}_{2}$ (sulfur dioxide), $\mathrm{NO}_{\mathrm{x}}$ (nitrogen oxide), $\mathrm{CO}$ (carbon monoxide), dust, NMVOC (nonmethane volatile organic compounds), and $\mathrm{NH}_{3}$ (ammonia). The social aspects are described by one indicator (employment in the energy sector), and six indicators (energy productiveness, energy raw material productiveness, renewable energy as a share of primary energy consumption, renewable energy as a share of electricity production, transport intensity of passenger transport, and transport intensity of goods transport) describe the economic aspects of sustainability in the energy sector. For these indicators, the Federal Government defines quantitative goals in their sustainability strategy and these goals were used for the analysis of the energy system.

In the following, we will measure whether the development of the energy sector is sustainable according to the goals set by the German government. To this end, we would like to draw conclusions from the economic theory of individual welfare measurement.

\section{Measuring Sustainability in the Energy Sector}

2.1. Comparing the Politically Defined and the Derived Sustainability Order. The sustainability order of a society can be derived from the observable market and societal actions of households, enterprises, and institutions and reveals their true preferences for sustainability, thereby allowing implicit conclusions to be drawn about the significance sustainability has for society. This approach is related to the theory of the individual welfare measurement, where a welfare measure is an instrument for drawing conclusions from the observable market actions of the consumers about their unobservable preference order [18-26]. This derived societal sustainability order has to be compared with the politically defined sustainability order of, in our case, the German Federal Government. The sustainability indicators therefore have the function of measuring the difference between the derived observable sustainable order and the politically defined order. The difference between these sustainable orders is the sustainability gap, determining the degree to which the development of society is (un)sustainable.

However, it should be noted that the sustainability order is always normatively defined and an objective assessment free of values and ethical assumptions is impossible [27, 28]. Sustainability always refers to the fact that state and society have to discuss and determine what they understand by "good" societal sustainable development and what meaning the three pillars of sustainability (economics, social, and ecology) therefore have for sustainable development. 
TABLE 1: Sustainability energy indicators for Germany.

\begin{tabular}{|c|c|c|c|c|c|c|c|c|c|c|}
\hline \multicolumn{11}{|c|}{ Sustainability indicators for Germany } \\
\hline & 1997 & 1998 & 1999 & 2000 & 2004 & 2006 & 2010 & 2015 & 2020 & 2050 \\
\hline \multicolumn{11}{|l|}{$\begin{array}{l}\text { (1) Energy and raw materials productivity } \\
(1994=100)\end{array}$} \\
\hline Energy & & & 120 & & & & 160 & & 200 & \\
\hline Raw materials & & & 117 & & & & 158 & & 200 & \\
\hline $\begin{array}{l}\text { (2) Emissions of the six greenhouse gases } \\
\text { covered by the Kyoto Protocol } \\
(1990=100)\end{array}$ & & & & 81 & & & 79 & & & \\
\hline \multicolumn{11}{|l|}{$\begin{array}{l}\text { (3) Proportion of energy consumption from } \\
\text { renewable energy }\end{array}$} \\
\hline in $\%$ primary energy consumption & & & & 2 & & & 4 & & & \\
\hline in $\%$ electricity consumption & & & & 6 & & & 13 & & & 50 \\
\hline \multicolumn{11}{|l|}{ (4) Mobility } \\
\hline \multicolumn{11}{|l|}{ Transport intensity $1999=100$} \\
\hline Passenger traffic & & & 100 & & & & 90 & & 78 & \\
\hline Goods traffic & & & 100 & & & & 98 & & 95 & \\
\hline \multicolumn{11}{|l|}{ (5) Air quality, $1990=100$} \\
\hline Air Quality & & & 54 & 52 & & & 30 & & & \\
\hline $\mathrm{NO}_{\mathrm{x}}$ & & & 54 & 52 & & & 30 & & & \\
\hline $\mathrm{SO}_{2}$ & & & 54 & 52 & & & 30 & & & \\
\hline $\mathrm{CO}$ & & & 54 & 52 & & & 30 & & & \\
\hline Dust & & & 54 & 52 & & & 30 & & & \\
\hline NMVOC & & & 54 & 52 & & & 30 & & & \\
\hline $\mathrm{NH}_{3}$ & & & 54 & 52 & & & 30 & & & \\
\hline \multicolumn{11}{|l|}{ (6) Employment } \\
\hline Employment rate in \% & & & & 65.4 & & & 70 & & & \\
\hline
\end{tabular}

Source: [14]

IEF-STE 2011

2.2. Index of Sustainable Development (ISD): Measuring the Sustainability in the German Energy Sector. Within the scope of the sustainability measurement, sustainability can be measured as a quotient of two linear functions, which relate the indicator and its objective, set by the government, to the real development of this indicator, representing the observable market actions of the consumers. For this analysis of sustainability measurements, we developed the index of sustainable development (ISD).

The ISD calculates the degree to which a society is in accord with the sustainability goals defined by the government. The ISD combines the chosen indicators $\left(I_{n}\right)$ the government has perceived as important for sustainable development of the energy sector:

$$
\mathrm{ISD}=\sum_{n=1}^{n} I_{n}, \quad n=1, \ldots, N
$$

where $n$ defines the single indicator and $N$ defines the total number of all indicators. Every indicator $I_{n}$ therefore documents an aspect that the Federal Government considers as important for sustainable development in the energy sector.

Figure 1 presents our concept in an abstract manner. The figures given do not represent real values but are used to clarify the concept.

As Figure 1 shows, the single indicators of the ISD measure the sustainability gap, that is, the difference between the "area" in Figure 1 defined as sustainable by the defined sustainability goals and the "area" of the derived, aggregated preferences of society. If these areas match, the defined and the derived sustainability order coincide. However, they may differ: society can lag behind the politically defined sustainability targets (unsustainable area), or it may outperform these targets. We call this a sustainability surplus. We ill 


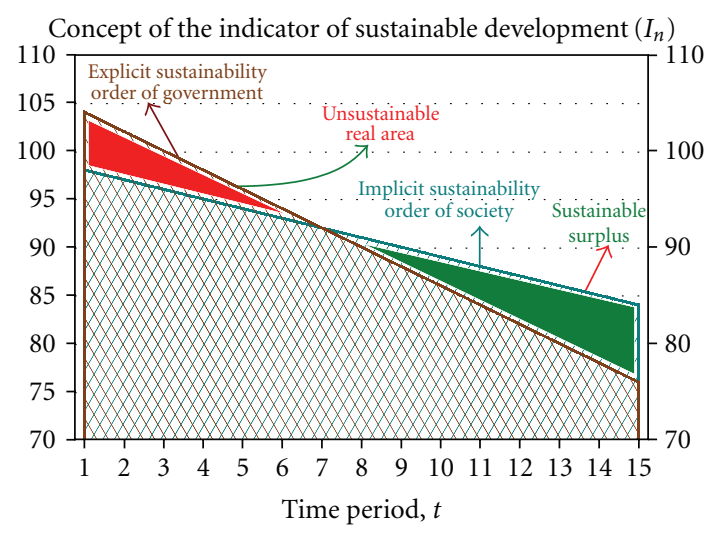

Figure 1: Concept of the indicators in the index of sustainable development. Source IEF-STE 2011. (this figure does not represent real values but makes the concept clear.)

later address the importance of handling this surplus in the context of our ISD.

The two areas can be examined in relation to each other with the definite integral above the respective area. Thus, it can be determined whether the development is sustainable for this indicator. Therefore, the development of the sustainability indicator can be determined over time $t=1, \ldots, T$ :

$$
I_{n}(t)=\frac{\int_{t=1}^{T} \underbrace{f(t)}_{\text {Area 1 }}}{\int_{t=1}^{T} \underbrace{g(t)}_{\text {Area 2 }}}, \quad t=1, \ldots, T .
$$

The following equation elucidates the relationship between the (implicit) sustainability order derived from social activities and the defined sustainability order of the German Federal Government:

$I_{n}(t)$

$$
\begin{aligned}
= & \frac{\int_{t=1}^{T} \underbrace{X_{\text {Real }}(t)}_{\text {Real-Area }}}{\int_{t=1}^{T} \underbrace{X_{\text {SD }}(t)}_{\text {SD-Area }}}, t=1, \ldots, T \\
= & \frac{\text { Real order (implicit sustainability order) of society }}{\text { Explict sustainability order of the government }} .
\end{aligned}
$$

Or for a linearized function, as will be used in the following:

$$
I_{n}(t)=\frac{\int_{t=1}^{T}\left(X_{\text {Real }}+a(t)\right) d t}{\int_{t=1}^{T}\left(X_{\mathrm{SD}}+a(t)\right) d t} \geq 1, \quad t=1, \ldots, T .
$$

Hence, the indicator $I_{n}(t)$ measures the sustainability of a system over a certain time period $t=1, \ldots T$ and not just at a certain date. If the index is greater than or equal to one
$\left(I_{n}\right.$, ISD $\left.\geq 1\right)$, the development is sustainable according to the government's predefined order.

Every element $\left(I_{n}\right)$ of the sustainability index reveals progress and challenges to a pursuit of sustainable development, and it demonstrates where political action is needed to achieve sustainable development (orientation function of the ISD). The ISD summarizes the single indicators $\left(I_{n}\right)$ to a superordinate indicator and calculates the degree to which sustainable development has been achieved or not in the energy sector.

We chose this type of index because the various energyrelated indicators of the German sustainable development strategy reveal a very heterogeneous picture of the development of the German energy sector, and this heterogeneity is difficult to aggregate and to communicate to the public. An overall indicator makes clear to the public how all the different aspects of the energy sector develop together. Thus the overall sustainability index can be interpreted as a balance sheet of the energy sector, which summarizes the different aspects of the sector. The use of this index has the advantage that the sustainability of a specific development can be analyzed in a three-step hierarchical procedure:

(i) in the first step, one determines the development of the single indicator and examines whether, for example, carbon dioxide emissions are in line with the sustainability objectives;

(ii) in the second step, one determines the development of the single pillar;

(iii) in the third step, one determines whether the total system is developing in a sustainable manner.

In every step, this procedure therefore delivers information on the level of sustainability that has been attained and offers political decision makers information on the analyzed system that could be used to develop measures and instruments, which counteract undesired unsustainable trends.

In the following section, we will calculate the single indicators of the three pillars of the German sustainability concept according to the equation given above and thereby determine the change of the indicators over time.

2.3. Measuring the Single Indicators. In the first step of the analysis, we will examine whether every single indicator develops in a sustainable manner. In this context, the question has to be answered of how an overfulfillment of sustainability goals should be interpreted. The sustainability concept of the Federal Government does not offer a method for solving this problem, as the Government does not define the area above the sustainability target line (sustainable surplus; see Figure 1). In the following section, we offer two interpretations of how this area could be treated: sustainability surplus compensation and sine sustainability surplus compensation.

2.3.1. Sine Sustainability Surplus Compensation (SSSC). SSSC means that an overfulfillment of the sustainability goal is simply interpreted as meeting the sustainability target. Therefore, an overfulfillment of a sustainability indicator 
cannot compensate for the underfulfillment of another sustainability target.

With the assumption of sine sustainability surplus compensation, we obtain the following equation:

$x_{n}=\frac{F(n)}{\mathrm{SD}_{G}(n)}=\frac{\text { actual results }}{\text { sustainability }}$ u. d. N, $\quad \begin{array}{r}x_{n} \geq \begin{array}{l}1 \longrightarrow x_{n}=1, \\ n=1, \ldots, N .\end{array}\end{array}$

This means that all indicator values above 1 are interpreted as 1: the indicator meets its sustainability target.

2.3.2. Sustainability Surplus Compensation (SSC). If SSC is allowed, the overfulfillment of one indicator could be completely compensated by one or more underperforming indicators.

This concept can be described by the following equation:

$$
x_{n}=\frac{F(n)}{\operatorname{SD}_{G}(n)} \text { u. d. N, } \quad x_{n} \geq 1 \longrightarrow x_{n}=1, n=1, \ldots, N \text {. }
$$

Thus, both compensation methods (SSSC, SSC) define the guardrails and the degree of freedom a system has in the pursuit of sustainable development. If SSC is permitted, the sustainability goal could probably be achieved more easily: distinct improvements of one indicator can compensate for the weaknesses of a different indicator. This procedure is implicitly oriented towards the concept of weak sustainability [4], which allows compensation between nature, human capital, and artificial capital as long as the capital stock is at least constant.

For the political implementation of the sustainability approach, the SSC means that the need for political action and control may be reduced and that the microcontrol of individual circumstances represented by the individual indicators is not always necessary. The implementation of the sustainability strategy does not necessarily require every indicator to meet its targets if there are sufficient indicators with a sustainability surplus. For SSSC, the reverse will hold. This concept implicitly follows strong sustainability [4], where artificial capital cannot substitute the natural endowments.

In the following section we combine the single indicators to the superordinate index of sustainable development. For this transformation we can use two different procedures: the equal pillar and the equal indicator methods.

\subsection{Measuring the Index of Sustainable Development}

2.4.1. Equal Pillar Method. In the equal pillar method the three pillars are treated equally; however, many indicators the pillar may have. Therefore the equivalence of the indicators and the three pillars can only be achieved at the same time if the number of indicators is the same for all three pillars. If the indicators are not equally distributed, this leads to a different weighting of the three pillars by the assessment of sustainable development with the index of sustainable development:

$$
\begin{array}{r}
x_{n}=\frac{F(n)}{\operatorname{SD}_{G}(n)} \text { u. d. N, } \\
\text { ISD }_{\text {total }}=\sum_{j=1}^{3} \frac{\sum_{n=1}^{M} x_{n}}{3},
\end{array}
$$

$j=$ columns, $M=$ number of indicators $\mathrm{n}$ in a sustainability pillar.

2.4.2. Equal Indicator Method. In the second procedure, all indicators are treated equally whatever number of indicators may be in one pillar. Therefore, the three pillars are not treated equally if the number of indicators differs. For the calculation of the equal indicator method, we obtain the following formula:

$$
\begin{gathered}
x_{n}=\frac{F(n)}{\operatorname{SD}_{G}(n)} \text { u. d. N, } x_{n} \geq 1 \longrightarrow x_{n}=1, \\
\operatorname{ISD}=\left(\sum_{n=1}^{N} x_{n}\right) \cdot \frac{1}{N} .
\end{gathered}
$$

For the calculation of the superordinate indicator ISD by the equal indicator method the sum of all single indicators is divided by the total number of single indicators.

In the following section we will carry out the calculations for 15 indicators which we selected for the energy sector from the German sustainability strategy.

\section{Results of Sustainability Measurement}

Our linear regression model is based on data from German institutions [29-34]. Based on this model analysis, the index of sustainable development (ISD) is calculated by summarizing the single indicators to form an overall index. We use both the equal indicator method and the equal pillar method, and we make a distinction between sine sustainability surplus compensation (SSSC) and sustainability surplus compensation (SSC). The results are summarized in Table 2.

For the first step of our calculation method, we can conclude for the single indicators that five indicators (employment, $\mathrm{SO}_{2}$ emissions, $\mathrm{CO}$ emissions, NMVOC emissions, and fine dust) of the German energy system are developing in a sustainable way and that ten indicators (energy productivity, energy raw material productivity, renewable energy on primary energy production, renewable energy on electricity consumption, passenger and goods traffic, $\mathrm{CO}_{2}$ emissions, $\mathrm{NO}_{\mathrm{x}}$ emissions, $\mathrm{NH}_{3}$ emissions, and air quality) are not meeting the sustainability goals of the German Government.

In the second step, for the development of the three pillars of sustainability, we detected a basic pattern, despite the heterogeneity of the results. The economic pillar does not develop in a sustainable way regardless of the calculation method, whereas the social pillar develops in a sustainable way even with different calculation methods. The ecological pillar shows a more inhomogeneous picture. In the case of the sustainability surplus compensation method, the ecological pillar develops in a sustainable way, whereas in the case of sine sustainability surplus compensation the ecological pillar does not develop in a sustainable way.

In the third step, we found a heterogeneous development of the energy system.

3.1. Equal Indicator Method. Table 2 shows that, under the assumption of sustainability surplus compensation and by 
TABLE 2: Results of the index of sustainable development in the energy sector.

\begin{tabular}{|c|c|c|c|c|}
\hline \multicolumn{5}{|c|}{ Calculation of the index of sustainable development in the energy sector } \\
\hline & \multicolumn{2}{|c|}{ Equal indicator method } & \multicolumn{2}{|c|}{ Equal pillar method } \\
\hline & SSC & SSSC & SSC & SSSC \\
\hline \multicolumn{5}{|l|}{ Economic } \\
\hline Energy productivity & 0.881 & 0.881 & 0.881 & 0.881 \\
\hline Energy raw material productivity & 0.520 & 0.520 & 0.520 & 0.520 \\
\hline \multicolumn{5}{|l|}{ Renewable energy } \\
\hline on primary energy production & 0.895 & 0.895 & 0.895 & 0.895 \\
\hline on electricity consumption & 0.930 & 0.930 & 0.930 & 0.930 \\
\hline \multicolumn{5}{|l|}{ Transport intensity } \\
\hline Passenger traffic & 0.983 & 0.983 & 0.983 & 0.983 \\
\hline Goods traffic & 0.925 & 0.925 & 0.925 & 0.925 \\
\hline Total & 5.134 & 5.134 & 5.134 & 5.134 \\
\hline Total ISD economic & 0.856 & 0.856 & 0.856 & 0.856 \\
\hline \multicolumn{5}{|l|}{ Social } \\
\hline Employment & 1.330 & 1.000 & 1.330 & 1.000 \\
\hline Total ISD social & 1.330 & 1.000 & 1.330 & 1.000 \\
\hline \multicolumn{5}{|l|}{ Ecological } \\
\hline $\mathrm{CO}_{2}$ & 0.920 & 0.920 & 0.920 & 0.920 \\
\hline $\mathrm{NO}_{\mathrm{x}}$ & 0.970 & 0.970 & 0.970 & 0.970 \\
\hline $\mathrm{SO}_{2}$ & 1.550 & 1.000 & 1.550 & 1.000 \\
\hline $\mathrm{CO}$ & 1.180 & 1.000 & 1.180 & 1.000 \\
\hline Fine dust & 3.096 & 1.000 & 3.096 & 1.000 \\
\hline NMVOC & 1.180 & 1.000 & 1.180 & 1.000 \\
\hline $\mathrm{NH}_{3}$ & 0.870 & 0.870 & 0.870 & 0.870 \\
\hline Air quality & 0.960 & 0.960 & 0.960 & 0.960 \\
\hline Total & 10.726 & 7.720 & 10.73 & 7.72 \\
\hline Total ISD ecological & 1.341 & 0.965 & 1.341 & 0.965 \\
\hline Total & 17.1899 & 13.8542 & 17.1899 & 13.8542 \\
\hline \multirow{2}{*}{ Total ISD } & 1.1460 & 0.9236 & 1.1755 & 0.9402 \\
\hline & & & & IEF-STE 20 \\
\hline
\end{tabular}

using the equal indicator method, the development of the energy sector can be considered as sustainable, because the ISD is greater than one:

$$
\begin{aligned}
& \mathrm{ISD}_{\mathrm{EI}}^{\mathrm{SSC}} \\
& =\left[\left(I_{\mathrm{SD}_{\mathrm{Ef}}}+I_{\mathrm{SD}_{\mathrm{ER}}}+I_{\mathrm{SD}_{\mathrm{RP}}}+I_{\mathrm{SD}_{\mathrm{RS}}}+I_{\mathrm{SD}_{\mathrm{Pkm}}}+I_{\mathrm{SD}_{\mathrm{tkm}}}\right)+\left(I_{\mathrm{SD}_{\mathrm{EE}}}\right)\right. \\
& +\left(I_{\mathrm{SD}_{\mathrm{CO}_{2}}}+I_{\mathrm{SD}_{\mathrm{NO}}}+I_{\mathrm{SD}_{\mathrm{CO}}} I_{\mathrm{SD}_{\mathrm{SO}_{2}}}+I_{\mathrm{SD}_{\text {Dust }}}+I_{\mathrm{SD}_{\mathrm{Air}}}\right. \\
& \left.\left.+I_{\mathrm{NMVOC}}+I_{\mathrm{NH}_{3}}\right)\right] \cdot \frac{1}{15}=1.1460,
\end{aligned}
$$$$
\mathrm{ISD}_{\mathrm{EI}}^{\mathrm{SSC}}>1
$$

It can be concluded from an index value of 1.1460 that the implicit order of society has overfulfilled the explicit order by about $14.6 \%$.

If one assumes that underfulfillment of an indicator cannot be compensated for through overfulfillment of another indicator, then the development of the German energy sector is not sustainable, as the equation shows:

$$
\begin{aligned}
& \mathrm{ISD}_{\mathrm{EI}}^{\mathrm{SSSC}} \\
& =\left[\left(I_{\mathrm{SD}_{\mathrm{Ef}}}+I_{\mathrm{SD}_{\mathrm{ER}}}+I_{\mathrm{SD}_{\mathrm{RP}}}+I_{\mathrm{SD}_{\mathrm{RS}}}+I_{\mathrm{SD}_{\mathrm{Pkm}}}+I_{\mathrm{SD}_{\mathrm{tkm}}}\right)+\left(I_{\mathrm{SD}_{\mathrm{EE}}}\right)\right. \\
& +\left(I_{\mathrm{SD}_{\mathrm{CO}_{2}}}+I_{\mathrm{SD}_{\mathrm{NO}_{x}}}+I_{\mathrm{SD}_{\mathrm{CO}}} I_{\mathrm{SD}_{\mathrm{SO}_{2}}}+I_{\mathrm{SD}_{\text {Dust }}}+I_{\mathrm{SD}_{\mathrm{Air}}}\right. \\
& \left.\left.+I_{\mathrm{NMVOC}}+I_{\mathrm{NH}_{3}}\right)\right] \cdot \frac{1}{15}=0.9236 .
\end{aligned}
$$

In the case of the index value of 0.9236 , the implicit order of society achieved the explicit order of the government only with $92 \%$.

3.2. Equal Pillar Method. If one applies the equal pillar method, a different picture emerges. If sustainability surplus compensation is allowed, then the energy system is on a 
TABLE 3: Sustainability indicators of the German government: intergenerational equity.

\begin{tabular}{|c|c|c|c|c|c|c|c|c|c|}
\hline & $1997 \quad 1998$ & 1999 & 2000 & 2004 & 2006 & 2010 & 2015 & 2020 & 2050 \\
\hline \multicolumn{10}{|l|}{ (I) Intergenerational equity } \\
\hline \multicolumn{10}{|l|}{$\begin{array}{l}\text { (1) Energy and raw materials productivity } \\
(1994=100)\end{array}$} \\
\hline Energy & & 120 & & & & 160 & & 200 & \\
\hline Raw materials & & 117 & & & & 158 & & 200 & \\
\hline $\begin{array}{l}\text { (2) Emissions of the six greenhouse gases } \\
\text { covered by the Kyoto Protocol }(1990=100)\end{array}$ & & & 81.13 & & & 79 & & & \\
\hline \multicolumn{10}{|l|}{$\begin{array}{l}\text { (3) Proportion of energy consumption from } \\
\text { renewable energy }\end{array}$} \\
\hline in $\%$ primary energy consumption & & & 2.1 & & & 4.2 & & & \\
\hline in $\%$ electricity consumption & & & 6.3 & & & 12.5 & & & 50 \\
\hline $\begin{array}{l}\text { (4) Land use for housing and transport: increase } \\
\text { in ha per day }\end{array}$ & & & 129 & & & & & 30 & \\
\hline $\begin{array}{l}\text { (5) Development of stocks of selected animal } \\
\text { species }(1995=100)\end{array}$ & & 98.2 & 95.4 & & & & & & \\
\hline (6) Public finance deficit: in $\%$ of GDP & & 1.6 & 1.3 & 0.5 & 0 & & & & \\
\hline $\begin{array}{l}\text { (7) Provision for future economic stability: gross } \\
\text { capital formation in relation to GDP }\end{array}$ & & 22.6 & 22.5 & & & & & & \\
\hline $\begin{array}{l}\text { (8) Innovation: private and public expenditure on } \\
\text { research and development }\end{array}$ & & 2.45 & 2.46 & & & 3 & & & \\
\hline \multicolumn{10}{|l|}{ (9) Education and training } \\
\hline 25-year olds having completed education & & & 6 & & & 9.5 & & & \\
\hline $\begin{array}{l}\text { Those leaving secondary school without } \\
\text { qualifications }\end{array}$ & & & 9 & & & 4 & & & \\
\hline University entrance rate & & & 30.2 & & & 40 & & & \\
\hline
\end{tabular}

sustainable development path:

$$
\begin{aligned}
\mathrm{ISD}_{\mathrm{EP}}^{\mathrm{SSC}} & =\frac{1}{3} \mathrm{ISD}_{\mathrm{Econ}}+\frac{1}{3} \mathrm{ISD}_{\mathrm{Soz}}+\frac{1}{3} \mathrm{ISD}_{\mathrm{Eco}}, \\
\mathrm{ISD}_{\mathrm{EP}}^{\mathrm{SSC}} & =\frac{1}{3}\left[\frac{\sum_{i=1}^{M_{1}} I_{i}}{M_{1}}\right]+\frac{1}{3}\left[\frac{\sum_{i=1}^{M_{2}} I_{i}}{M_{2}}\right]+\frac{1}{3}\left[\frac{\sum_{i=1}^{M_{3}} I_{i}}{M_{3}}\right] \\
& =\frac{1}{3}\left[\frac{\sum_{j=1}^{3} \sum_{i=1}^{M_{j}} I_{i, j}}{M_{j}}\right]=1.1755 \\
\mathrm{ISD}_{\mathrm{EP}}^{\mathrm{SSC}} & =\frac{1}{3}(0.856+1.33+1.341)=1.1755, \\
\mathrm{ISD}_{\mathrm{EP}}^{\mathrm{SSC}} & >1 .
\end{aligned}
$$

The implicit order of society has overfulfilled the explicit order by about $17 \%$.

If sustainability surplus compensation (SSSC) is not accepted, then the energy system is not sustainable:

$$
\begin{gathered}
\operatorname{ISD}_{\mathrm{EP}}^{\mathrm{SSSC}}=\frac{1}{3}(0.856+1.0+0.965)=0.9402, \\
\operatorname{ISD}_{\mathrm{EP}}^{\mathrm{SSSC}}<1 .
\end{gathered}
$$

In this case, the implicit order of society has missed the explicit order of the government.

We can therefore summarize that, if the sustainability surplus compensation concept is allowed, it can be demonstrated with both methods-the equal pillar and the equal indicator-that the German energy system is developing in a sustainable direction according to the sustainability goals set by the German Government. If sustainability surplus compensation is not allowed, then we see that the energy sector is developing in an unsustainable direction according to both calculation methods.

\section{Conclusions: The Three Steps to Measure Sustainability}

We have shown that it is possible to aggregate sustainability indicators to one single overall index. The ISD enables us to define in a single index whether a system or its subsystems, described by a multipillar indicator sustainability system, are sustainable or not. A prerequisite for the application of ISD is defined indicators and targets.

To exemplify the method we have applied, we answer the question of whether the German energy sector is developing in a sustainable manner. Our approach helps to understand where political action is needed in order to 
TABLE 4: Sustainability indicators of the German government: quality of life.

\begin{tabular}{|c|c|c|c|c|c|c|c|c|c|}
\hline & 1997 & 1998 & 1999 & 2000 & 2004 & 2006 & 2010 & 2015 & 2020 \\
\hline \multicolumn{10}{|l|}{ (II) Quality of life } \\
\hline \multicolumn{10}{|l|}{ (10) Economic prosperity } \\
\hline GDP per capita in 1995 prices & & & 23281 & 23950 & & & & & \\
\hline \multicolumn{10}{|l|}{ (11) Mobility } \\
\hline \multicolumn{10}{|l|}{ Transport intensity $1999=100$} \\
\hline Passenger traffic & & & 100 & & & & 90 & & 78 \\
\hline Goods traffic & & & 100 & & & & 98 & & 95 \\
\hline Proportion of freight transported by rail & & & $15 \%$ & & & & & $25 \%$ & \\
\hline Proportion of inland shipping & $8 \%$ & & & & & & & $14 \%$ & \\
\hline \multicolumn{10}{|l|}{ (12) Nutrition } \\
\hline Proportion of organic farming in \% & & & & 3.2 & & & 20 & & \\
\hline Nitrogen surplus (kg/ha) & & & & 116.6 & & & 80 & & \\
\hline \multicolumn{10}{|l|}{ (13) Air quality } \\
\hline Concentration of air pollution $1990=100$ & & & 54 & 52 & & & & 30 & \\
\hline \multicolumn{10}{|l|}{ (14) Health } \\
\hline \multicolumn{10}{|l|}{ Premature mortality (below 65) } \\
\hline Women & & & 150 & & & & & & \\
\hline Men & & & 300 & & & & & & \\
\hline \multicolumn{10}{|l|}{ Satisfaction with health } \\
\hline Men & & & & 6.6 & & & & & \\
\hline Women & & & & 6.4 & & & & & \\
\hline \multicolumn{10}{|l|}{ (15) Crime } \\
\hline Burglaries involving a break-in & & & & 140000 & & & 126000 & & \\
\hline
\end{tabular}

Source: [14]

IEK-STE 2011

TABLE 5: Sustainability indicators of the German government: social cohesion.

\begin{tabular}{llllllllll}
\hline & 1997 & 1998 & 1999 & 2000 & 2004 & 2006 & 2010 & 2015 & 2020 \\
\hline (III) Social cohesion
\end{tabular}

(16) Employment

Employment rate

65,4

70

(17) Prospects for families

Full-time day-care facilities in the West German Länder

$\begin{array}{lcc}0-3 \text { years } & 2,2 & 30 \\ 3-6.5 \text { years } & 16,3 & 30 \\ 6.5-12.5 \text { years } & 3,4 & 30\end{array}$

(18) Equal opportunities

Comparison of gross annual earnings from fulltime employment (women and men aged between 35 and 39, West German Länder)

(19) Integration of foreign citizens

Foreign school leavers without secondary school-leaving Certificate

$17,1 \quad 17 \quad 16,7 \quad 16,1$

9

Source: [14] 
TABLE 6: Sustainability indicators of the German government: international responsibility.

\begin{tabular}{|c|c|c|c|c|c|c|c|c|c|}
\hline & 1997 & 1998 & 1999 & 2000 & 2004 & 2006 & 2010 & 2015 & 2020 \\
\hline \multicolumn{10}{|l|}{ (IV) International responsibility } \\
\hline (20) Public development cooperation (in \% GDP) & & & 0.27 & & & 0.33 & & & \\
\hline \multicolumn{10}{|l|}{ (21) Open markets } \\
\hline EU imports from developing countries (EUR billion) & 263 & 268 & 304 & 420 & & & & & \\
\hline
\end{tabular}

Source: [14]

IEK-STE 2011

achieve sustainable development. However, as demonstrated with the ISD, different calculation methods can result in a different assessment of sustainability, as the assessment of the performance of a country would differ depending on whether it was measured by the GDP or the MEW.

Despite the heterogeneity of the results, a basic pattern is visible in the energy sector. The economic pillar does not develop in a sustainable way, regardless of the calculation method, whereas the social pillar develops in a sustainable way, even with different calculation methods. The ecological pillar shows a more inhomogeneous picture. If the sustainability surplus compensation concept is allowed, it can be demonstrated with both methods-the equal pillar and the equal indicator-that the German energy system is developing in a sustainable direction. If surplus compensation is not allowed, then we see that the ecological pillar of the energy sector is developing in an unsustainable direction according to both calculation methods.

Reflecting that, we suggest that every societal institution should define its sustainable strategy and goals and also determine a calculation method, in order to make clear how the overfulfillment will be handled.

It is of great importance for the calculation of a system's sustainability whether the equal pillar or the equal indicator method is applied.

For the development of a sustainable system, we therefore suggest a three-step procedure:

(i) in the first step, the system under examination has to be defined (e.g., the energy system or the whole national economy) and indicators have to be selected that can describe the system;

(ii) in the second step, quantitative goals for the sustainability strategy have to be defined in a societal decision making process, thus creating a sustainable pathway for society;

(iii) last, but not least, the calculation method has to be chosen that allows the normative sustainability order to be compared with the actual order, thereby determining whether the society is "better off."

This three-step method facilitates greater transparency with respect to both the sustainability measurement itself and the communication to society.

\section{Appendix}

\section{Key Themes and Indicators of the German Sustainability Strategy}

For intergenerational equity, see Table 3. For quality of life, see Table 4 . For social cohesion, see Table 5. For international responsibility, see Table 6 .

\section{References}

[1] W. Nordhaus and J. Tobin, Is growth obsolete?, Columbia University Press, New York, NY, USA, 1972.

[2] C. W. Cobb and J. B. Cobb, Eds., The Green National ProductA proposed Index of Sustainable Economic Welfare, University Press of America, Lanham, MD, USA, 1994.

[3] E. Neumayer, Ed., Weak versus strong sustainability, Edward Eldgar Publishing, Cheltenham, UK, 1999.

[4] E. Neumayer, Weak Versus Strong Sustainability. Exploring the Limits of Two Opposing Paradigms, Edward Elgar, Cheltenham, UK, 2003.

[5] P. Bartelmus, "SEEA-2003: Accounting for sustainable development?” Ecological Economics, vol. 61, pp. 613-616, 2007.

[6] P. Bartelmus, "Green accounting," in Encyclopedia of Earth, 2007.

[7] J. R. Vincent, "Green accounting: from theory to practice," Environment and Development Economics, vol. 5, pp. 13-24, 2000.

[8] United Nations, Agenda 21, United Nations, New York, NY, USA, 1992.

[9] United Nations, Indicators of Sustainable Development: Guidelines and Methodologies, United Nations, New York, NY, USA, 1996.

[10] United Nations, Indicators of Sustainable Development: Guidelines and Methodologies, United Nations, New York, NY, USA, 2001.

[11] United Nations, Indicators of Sustainable Development: Guidelines and Methodologies, United Nations, New York, NY, USA, 2007.

[12] O. J. Kuik and A. J. Gilbert, "Indicators of sustainable development," in Handbook of Environmental and Resource Economics, J. C. J. M. Van Den Bergh, Ed., pp. 722-730, Edward Elgar, Cheltenham, UK, 2002.

[13] H. Bossel, Indicators for Sustainable Development: Theory, Method, Applications. A Report to the Balaton Group, Winnipeg, Manitoba, Canada, 1999. 
[14] German Federal Government, Perspectives for GermanyOur Strategy for Sustainable Development, German Federal Government, Berlin, Germany, 2002.

[15] H. Wiesmeth, Umweltökonomie, Springer, Heidelberg, Germany, 2003

[16] H. Schlör, J.-F. Hake, and R. Eich, "Evaluation of the German sustainability strategy," World Resource Review, vol. 16, no. 3, pp. 391-416, 2004.

[17] World Commission on Environment and Development (WCED), Our Common Future, Oxford University Press, New York, NY, USA, 1987.

[18] H. Funke, G. Hacker, and J. Voeller, "Fishers circular test reconsidered," Schweizerische Zeitschrift für Volkswirtschaft und Statistik, vol. 115, pp. 677-688, 1979.

[19] M. Ahlheim, "Wohlfahrtsmessung im Umweltbereich," in Wohlfahrtsmessung-Aufgabe der Statistik im gesellschaftlichen Wandel, J. Chlumsky and R. Wiegert, Eds., pp. 199-217, Statistisches Bundesamt, Wiesbaden, Germany, 1996.

[20] M. Ahlheim and M. Rose, "Alte und neue Maße individueller Steuerlasten," FinanzArchiv, vol. 42, pp. 274-339, 1984.

[21] M. Ahlheim and M. Rose, Messung individueller Wohlfahrt, Springer, Heidelberg, Germany, 1989.

[22] A. C. Harberger, Taxation, Resource Allocation, and Welfare, National Bureau of Economic Research and the Brookings Institution, Princeton, NJ, USA, 1964.

[23] A. C. Harberger, "Three basic postulates for applied welfare economics: an interpretive essay," Journal of Economic Literature, vol. 9, no. 3, pp. 785-797, 1971.

[24] I. Fisher, "The best form of index number," Journal of the American Statistical Association, vol. 17, no. 133, pp. 535-537, 1921.

[25] I. Fisher, The Making of Index Numbers: A Study of Their Varieties, Tests, and Reliability, Houghton Boston, New York, NY, USA, 1927.

[26] N. G. Pierson, "Further considerations on index-numbers," The Economic Journal, vol. 6, no. 1, pp. 127-131, 1896.

[27] W. M. Lafferty, "The politics of sustainable development: global norms for national implementation," Environmental Politics, vol. 5, no. 2, pp. 185-208, 1996.

[28] W. Lafferty and J. Meadowcraft, Implementing Sustainable Development: Strategies and Initiatives in High Consumption Societies, Oxford University Press, Oxford, UK, 2000.

[29] Umweltbundesamt, "Nationale Trendtabellen für die deutsche Berichterstattung atmosphärischer Emissionen seit 1990," 2008, http://www.umweltbundesamt.de/emissionen/publikationen.

[30] Bundesministerium für Wirtschaft und Technologie, Energiedaten 2006, Bundesministerium für Wirtschaft und Technologie, Berlin, Germany, 2006, http://www.bmwi.de/Navigation/ Technologie-und-Energie/Energiepolitik/energiedaten.html.

[31] Bundesministerium für Wirtschaft und Technologie, Energiedaten 2008, Bundesministerium für Wirtschaft und Technologie, Berlin, Germany, 2008, http://www.bmwi.de/Navigation/ Technologie-und-Energie/Energiepolitik/energiedaten.html.

[32] Arbeitsgemeinschaft Energiebilanzen E.V., Auswertungstabellen zur Energiebilanz für die Bundesrepublik Deutschland 1990-2005, Arbeitsgemeinschaft Energiebilanzen e.V., Berlin, Germany, 2006.

[33] Arbeitsgruppe Umweltökonomische Gesamtrechnungen der Länder, Umweltökonomische Gesamtrechnungen der Länder Rohstoff- und Materialflüsse Analysen und Ergebnisse, Landesamt für Datenverarbeitung und Statistik Nordrhein, Düsseldorf, Germany, 2006.
[34] Statistisches Bundesamt, Umweltökonomische Gesamtrechnungen (UGR)_Ziele, Konzepte und methodische Grenzen, Statistisches Bundesamt, Wiesbaden, Germany, 2002. 


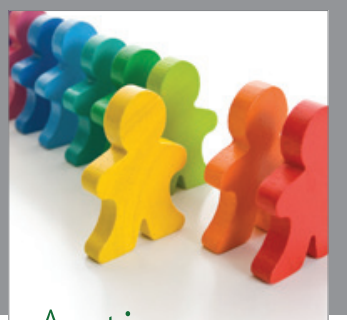

Autism

Research and Treatment
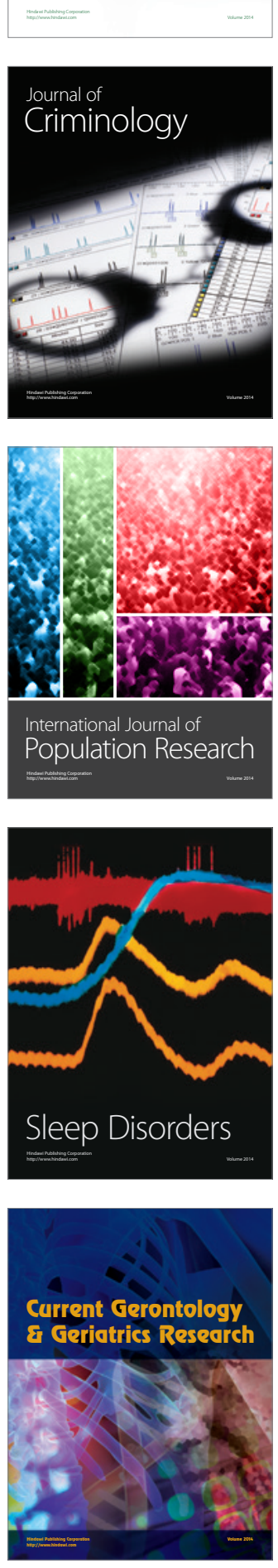
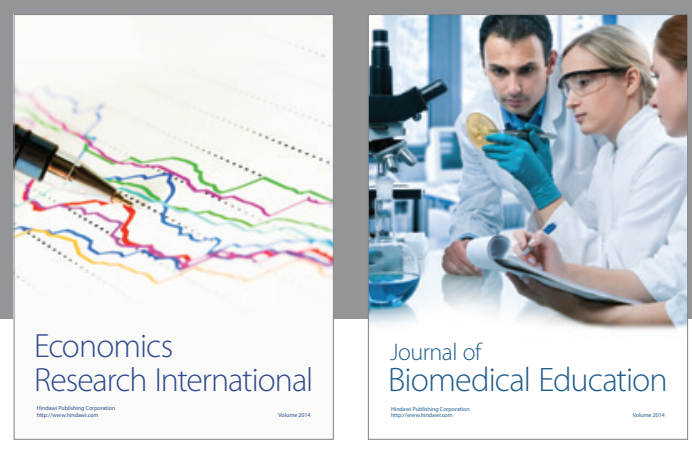

Journal of

Biomedical Education

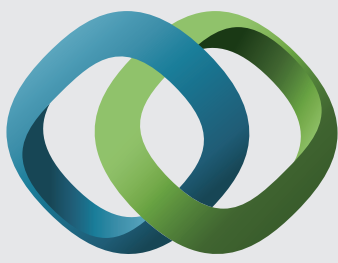

\section{Hindawi}

Submit your manuscripts at

http://www.hindawi.com
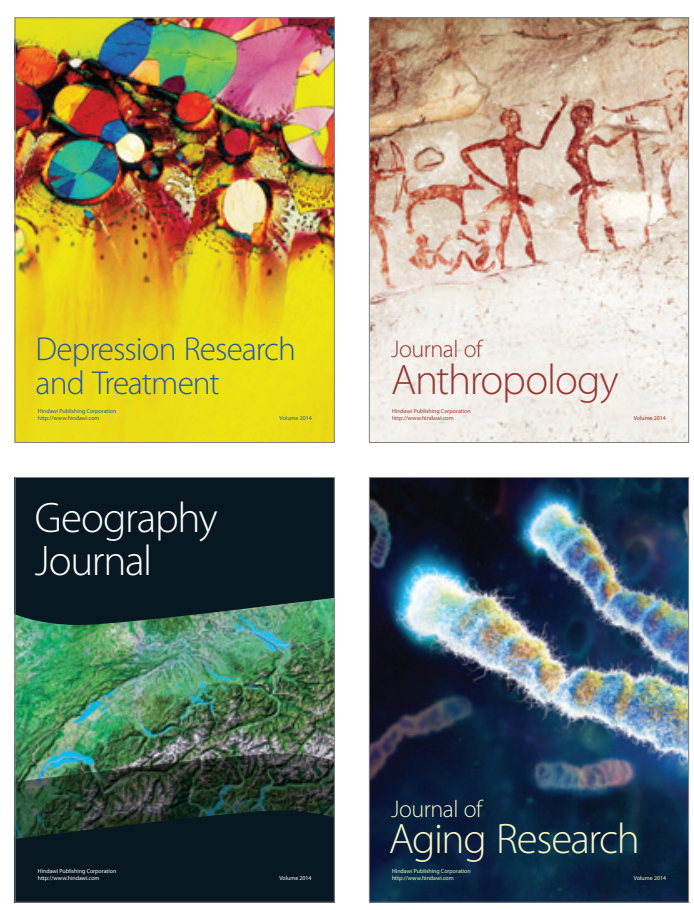

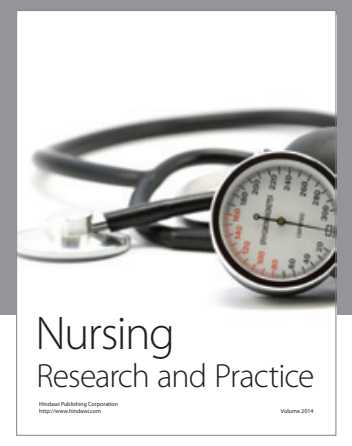

Nursing

Research and Practice

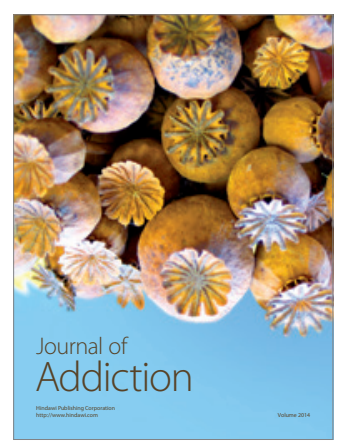

Child Development

Research

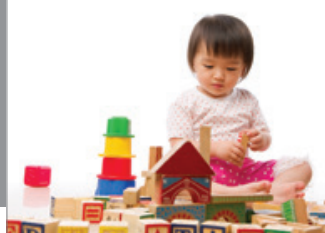

迥
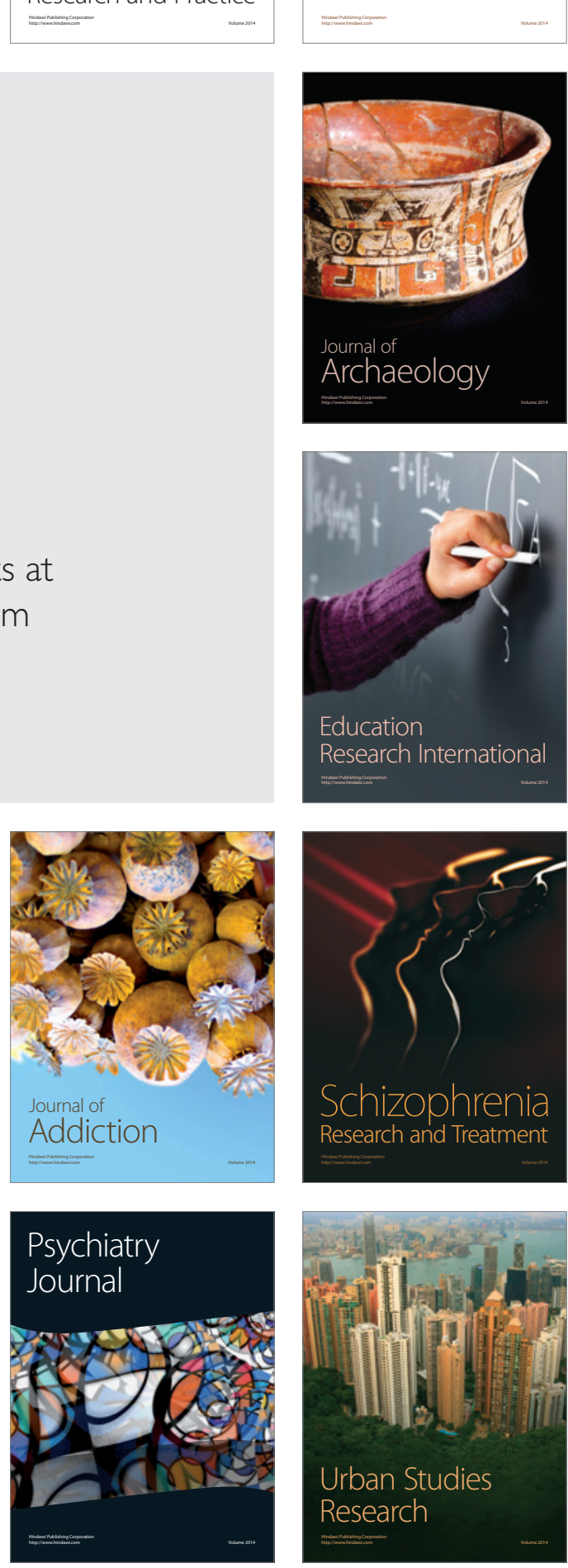